雇用形態は $88.6 \%$ 短期焦用で労働協約は殆えどない. 給与は出来棠制で家族 4.2 人で月 8.2 万円であり，林柴從

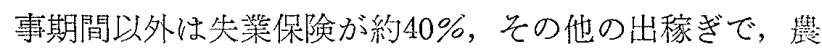
林兼業的なるのが25\%であった。振動障害に対する認譏 は低く，生活上の注意を払っていないものは47\%あり， 医師の検診を希望するものは55\%あるが，振動障害を経 験しても医師の検診を希望しないものが10\%もいた。振 動障害を経験しても受診したものはなく，その理由は， 大したことはない57.4\%，経済的理由 $11.1 \%$ ，病院が遠 い7.4\%などであった. 衛生教育と衛生管理の久如によ るものと洘㝋る。事業主の対策も余り積極的ではない。 労働組合がないか，あっても組織化が括くれていること も民間の振動障害問題を潜伏させる大さな要因と考兄る

\section{9. 電動皮易機による振動障害}

沒部真也，若葉金三，山川宗位（北大医公象衛生）

電動皮剩機はパルプ材の樹皮剝離に用いる回転刃を持 った一種の手持振動工具である.回転数は 1400 1600 $\mathrm{rpm}$, 重量は6.5 kg.

工具のハンドルに和ける振動を加速度計及び $1 / 3$ オタ ーブバンドフィルターで测定した.

スペクトルほ回転数に相当する $200 \sim 250 \mathrm{~Hz}$ から や低いあたりにピークを有し，より高い周波数带域にも かなりのエネルギーがある。

工具使用者40名（女28名, 男12名）について振動の影 響を調べた，年䍅は男女とも中年勫が主で，経駼年数は

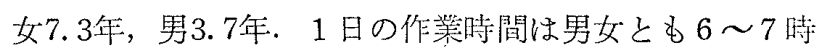
間で女では最近数年はやや短縮され $4 \sim 5$ 时間になって いる.

レイノ一現像は女では28名中 1 名にしか認められなか ったが，男では12名中 4 名に垫められた。

しびれは，多くはいたみやだるさを伴うもので女 68 \%，男50\%に認められ多くは夜中から朝方にかけて発症 している，女の場合，自䎐車のハンドルを長く握ってお れない，緛物・針任事を長くできない，包丁を長く握っ て执れないなど日常生活の不便が訴えられていることは 特徽的であった。

他覚的所見では，冷水浸漬試験結果異常者率は女で68 \%，男で42\%にみられたが，女より男で異常の程度が強 かった，種々の知覚検査でも，鈍麻は女で約70\%，男で 約 $40 \%$ そとめられた。

以上の結果から，電動皮剥機はチエンソー上り振動数
が高いが，この程度の範囲では症状のあらわれ方はチエ ンソーとほぼ同じと推定される，障害のあらわれ方，と くにレイノー現症の発現に性差があったがこの点につい ては更に症例をふやして検討したい。

とにかく，電動皮别機はチエンソーなどと同様の労働 衛生上の取扱いをらけるべき工具として行政的にも取上 ゲられるべきである。

\section{討 論}

渡部真也：皮膚温度覚テストは, 試験管に種々の温度 の水を入れたものを用いて行った，検查法，判定基準は 研究中の段階であるが，今回は，無感带 $30^{\circ}$ 以上，温覚 $34^{\circ}$ 以上, 冷覚 $28^{\circ}$ 以下を異常の疑われるものとした。

\section{0. $1 / 3$ オクターブバンド， ランダム振動の大きさ}

\section{三輪俊輔，米川善晴 (学衛研)}

ランダム振動の評洒法については，前報に於て，オク ターブバンドランダム振動の閾值及び等感度を測定して "振動の大きさのレベル"（単位V G L) を定めた. 又種 々の带域幅をもつランダム振動についてオクターブバン ド分析值（VAL）を前述の等感度曲線を用いてVA L 值とした．次に加法則の成立する “振動の大きさ”（単 位 VG) に下式で変換し，

$$
\left.\begin{array}{l}
\log V G=0.030 \mathrm{VGL}-1.20,1 \mathrm{VG} \text { 以下 } \\
\log \mathrm{VG}=0.023 \mathrm{VGL}-0.92,1 \mathrm{VG} \text { 以上 }
\end{array}\right\}
$$

更に荷重加算して全VG値を求めた。

$$
V G_{T}=V G_{M}+0.3\left\{\left(\Sigma V G_{i}\right)-V G_{M}\right\}
$$

振動台上での被検者実験の結果上記の計算值が振動の大 きさのレベルにしてさ3 dB 以内で一致する事を見出し た。

今回は1/3オクターブ分析値の場合について検討を加壳 た、まず第一に1/3オクターブバンドのランダム振動の等 感度由線を $20 \mathrm{~Hz}$ の正昡振動とランダム振動を一対比 較法により測定した，被検者10名，全身垂直，水平，手 の振動について実験した。この結果等感度曲線はオクタ ーブバンドランダム振動の場合の曲線とよく一致する事 を知った。

次に任意のバンド幅をもったランダム振動（前回オク ターブバンドの実験に用いたと同じ信号）を1/3オクター ブバンド分析器で分析し，その振動加速度值（V A L) を求め，オクターブバンド等感度由線を使ってVA と し，(1)式により V G 值とし，全 VG 值を下式より計算し 
た。

$$
\mathrm{VG}_{T}=\mathrm{VG}_{M}+0.13\left\{\left(\Sigma \mathrm{VG}_{i}\right)-\mathrm{VG}_{M}\right\}
$$

観測值と比較すると $\pm 3 \mathrm{~dB}$ 以内に入っている事を留っ た。

問題点：等感度曲線がランダム振動と正弦振動で，16 $\mathrm{Hz}$ 以下， $60 \mathrm{~Hz}$ 以上で多少相異する。特に $16 \mathrm{~Hz}$ 以下 の相違の原因は不明である，又 crest factor の異なる実 際の振動と上記評価法の対応は今後の検討を要する点と 考光られる。

\section{討 論}

富永洋志夫 (労研)：振動異荷の万法の違いによって 等感度浀線は異ってこないか。ある方法で振動を与光た
場合，変位振幅にそった等感度曲線を得た経 験がある が，機械インピーダンスの違いによるものだろうか。

渡部真也（北大医公賉衛生）：振動の障害性の評価に 等感度曲線を用いることについては餐義があり，むしろ 物理量を測定すること，特に周波数分析をすることが現 段階では望ましいと考える。しかし等感曲線はそれなり の意味もあるし，またソ連，チェコ，三浦の許容度提案 などと比较すると，何れも㓮波数が高くなるにつれて許 容加速度が大きくなってくるし，その傾斜も大凡近似し ているとみて，三輸の提案を受け入れてもよいと思う。 flatな特性と, weighting をした特性と両布で測定して おけば，三輪の提案の妥当性を検討することがでさるの でよいのではないか。

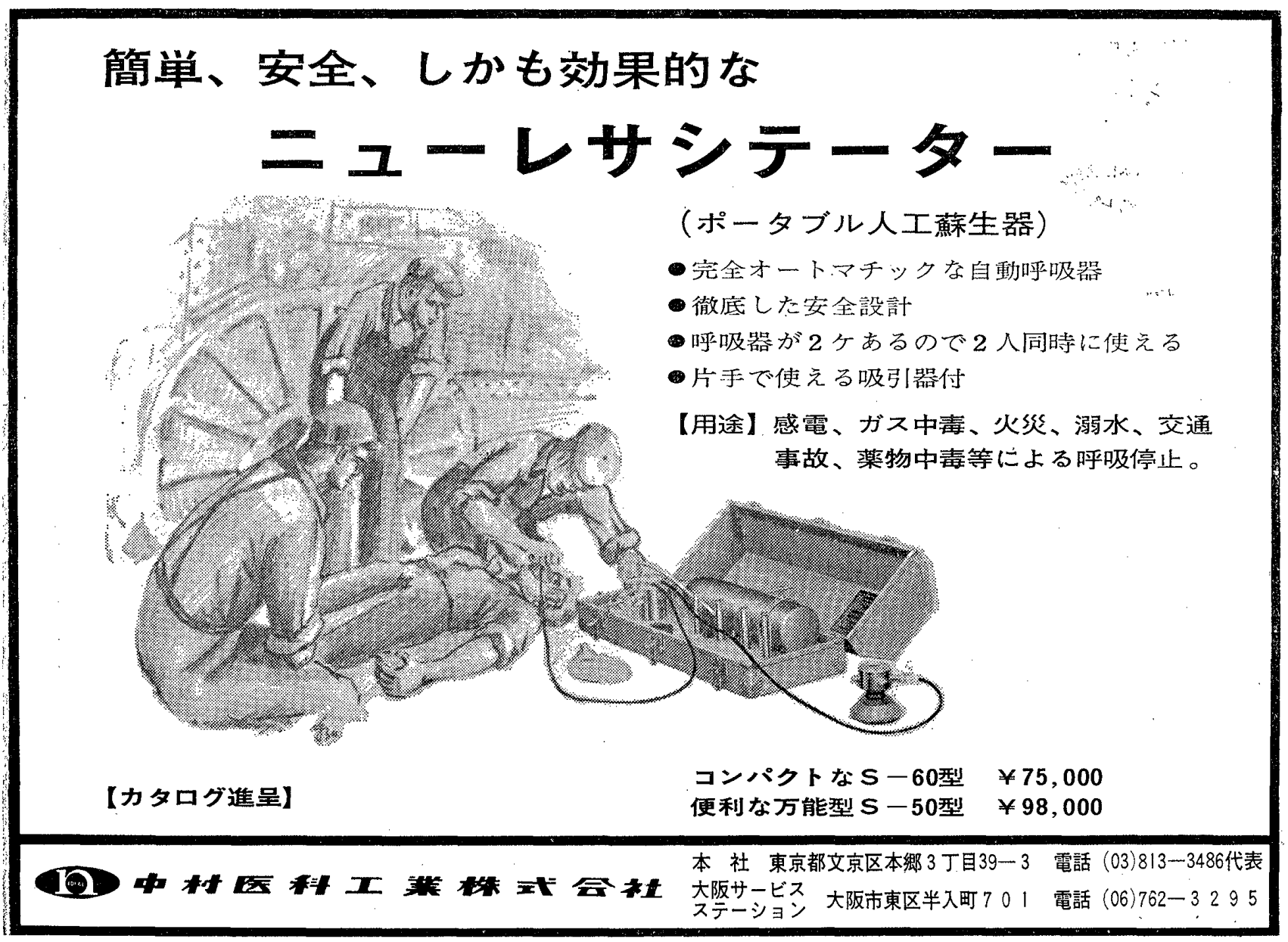

